\title{
Information Transparency and Earnings Management - Evidence from China's Multi-Tiered Capital Market System
}

\author{
Yong-Yi LI \\ No 18 Jinfeng Road, Tangjiawan, Zhuhai City, Guangdong Province, China \\ Beijing Normal University, Zhuhai / School of Management \\ liyongyi@bnuz.edu.cn
}

Keywords: Information disclosure, Transparency, Earnings management.

\begin{abstract}
How to better reduce asymmetric information and lower management flexibility has drawn much attention after a series of financial scandals. To this end, Shenzhen Stock Exchange (SZSE) finished the first appraisal of information disclosure of listed companies in 2001. Building on the work of the implementation of the appraisal, this paper investigates the relation between the information transparency and earnings management. We conclude that establishing the information disclosure system to force managers to provide more information can also lower their use of accruals-based earnings management.
\end{abstract}

\section{Introduction}

The corporate management authority has often tried to influence its corporate earnings information by selection of a variety of accounting methods (Healy 1999 [1]).The management or managers are likely to use the earnings management method to mislead those who use financial statements to press for the maximum corporate profit and stock value. To be more specific, the management and managers often use discretionary accruals to manipulate earnings and make the meet the specific objective and intent. The financial statements glossed over by this kind of conduct and intent may result in serious outcome for the aforesaid stakeholders and lead to the problem of information asymmetry. The information environment is likely to impose certain externalities on accounting information: a company's degree of information asymmetry can be decreased by an effective information disclosure system, which provides a transparent information environment for the company's financial reports and accounting earnings quality. Managers under stronger supervision are more likely to provide high-quality accounting reports that further promote improvements in corporate earnings quality. In summary, can the level of transparency in the information environment influence company earnings management behavior in the Chinese capital market? As there is still a lack of comprehensive research into these three factors in China, in this paper we investigate their interaction in the emerging Chinese stock market.

\section{Literature Review and Hypotheses Development}

The primary reason why some circumstance may lead to adverse selection or moral hazard is asymmetric information. Akerlof's(1970) [2]classic adverse-selection market has explained the significant impact of information asymmetry between buyer and seller on trading behavior and market efficiency. Likewise, in the security market, the asymmetric information between investors and managers not only makes investors not able to identify which firm is worth investing but also gives managers opportunities of ignoring investor's benefit. People have been wondering whether the listed firms in China inflate earnings to satisfy various inside and outside expectations, which is what we want to know. To better reduce asymmetric information and lower management flexibility, Shenzhen Stock Exchange (SZSE)established the information disclosure system. Therefore, this study attempts to verify whether there is a significant difference between before and after the implementation of the system and proposes the following hypothesis:

H1: Firms have lower earnings management after implementing the disclosure system. 
As is known to all, China is the largest developing country in the world and has completely different culture and political economy from the West. It is obvious that China acts as a good sample in widening the understanding of the qualities of accounting information disclosure. For example, there are some studies that find a two-way interactive relationship between information disclosure and corporate governance (Joe, 2003 [3]), show a negative impact of information transparency on capital cost (Wang and Jiang, 2004 [4]; Zeng and Lu, 2006 [5]), suggest that Firms with higher transparency have better corporate performance (Zhang et al., 2009 [6]; Chen and Wang, 2011 [7]), and indicate that the influence of information disclosure quality on the financial performance is nonlinear (Liand Zhang, 2013 [8]). While these papers make major contributes to the existing body of information transparency, their analyses do not entirely and separately investigate its effectiveness in decreasing earnings management based on China's multi-tiered capital market system. Therefore, this study proposes the following hypothesis:

H2: A greater level of information disclosure leads to lower earnings management.

Further, few studies have focused on corporate performance with regard to the changes in information disclosure rankings. For example, Jiao (2011) [9] document a positive correlation between changes in disclosure rankings and future earnings surprises. Lai, Liu, and Wang (2012) [10]suggest that through reducing information asymmetry, increased disclosure level induces managers to act in the best interest of shareholders, which improves capital investment efficiency. This indicates that corporate performance should be different when the information transparency rankings are changed. Accordingly, this study intends to examine if this influence exists in China and fill the gap in the current literature. This paper sets up the second hypothesis:

H3: Firms with a ranking upgrade are less likely to use earnings management than firms with a ranking downgrade.

\section{Methodology}

\section{Earnings Management}

In line with previous research (e.g., Kothari, Leone, and Wasley, 2005), this study employs discretionary accruals (DA) as a proxy for earnings management. To estimate DA, we use the cross-sectional modified Jones model as proposed by Kothari et al. (2005), which sort data by industries and seasons to estimate the coefficient for each independent variable, and also incorporates a performance measure to supplement other widely-used modified Jones models.

\section{Model Specification}

To test hypothesis $\mathrm{H} 1$ that the implementation of information disclosure leads to lower earnings management, we construct regression model (1)with a dummy variable level year and use three subsample data, the Main Board, SME Board, and the ChiNext market, for estimation, respectively. The regression model (1) is as follows:

$$
\mathrm{DA}_{\mathrm{t}}=\mathrm{a}_{1}+\mathrm{b}_{1} \text { levelyear }_{\mathrm{t}}+\mathrm{c}_{1} \text { big }_{\mathrm{t}}+\mathrm{d}_{1} \text { noa }_{\mathrm{t}-1}+\mathrm{e}_{1} \text { ocf }_{\mathrm{t}}+\sum \mathrm{f}_{1} \text { year }_{\mathrm{t}}+\varepsilon_{1}
$$

where

levelyear $\mathrm{r}_{\mathrm{t}}=1$ for post-disclosure system, and 0 otherwise;

$\operatorname{big} 4_{\mathrm{t}}=1$ if the company's audit firm is a Big 4 firm, and 0 otherwise;

noa $_{\mathrm{t}-1}=$ Net operating assets, Shareholders' equity - cash and marketable securities + total liability at the end of fiscal year $\mathrm{t}-1$, scaled by assets of fiscal year $\mathrm{t}-1$;

$\mathrm{ocf}_{\mathrm{t}}=$ Operating cash flow, Operating cash flow, scaled by assets of fiscal year $\mathrm{t}-1$.

Our second empirical hypothesis is to examine whether the implementation of the information disclosure ranking system (IDRS) rationalize earnings management. To test this hypothesis, we define years before 2001, years before 2005, and years before 2010 as the years before the implementation of the information disclosure system for the Main Board, SME Board, and the ChiNext market, respectively. To test hypothesis $\mathrm{H} 2$ that a greater level of information disclosure leads to lower earnings management, we construct regression model (2)with three dummy variables 
LEVEL4, LEVEL3, and LEVEL2, and use three subsample data, the Main Board, SME Board, and the ChiNext market, for estimation, respectively. The regression model (2) is as follows:

$$
\mathrm{DA}_{\mathrm{t}}=\mathrm{a}_{2}+\mathrm{b}_{2} \text { level }_{\mathrm{t}}+\mathrm{c}_{2} \text { level }_{\mathrm{t}}+\mathrm{d}_{2} \text { level }_{\mathrm{t}}+\mathrm{e}_{2} \text { big }_{\mathrm{t}}+\mathrm{f}_{2} \text { noa }_{\mathrm{t}-1}+\mathrm{g}_{2} \text { ocf }_{\mathrm{t}}+\sum \mathrm{h}_{2} \text { year }_{\mathrm{t}}+
$$

$\varepsilon_{2}$

where

level $2_{\mathrm{t}}=1$ if the firm's ranking is $\mathrm{C}$, and 0 otherwise;

level $3_{\mathrm{t}}=1$ if the firm's ranking is $\mathrm{B}$, and 0 otherwise;

level $4_{\mathrm{t}}=1$ if the firm's ranking is $\mathrm{A}$, and 0 otherwise;

Finally, to examine whether firms with ranking upgrades are likely to experience lower earnings management than those receiving downgrades, we replace the variable IDRS in regression model (3)with two dummy variables, no change and upgrade, and estimate regression model (3) as follows:

$$
\text { DA }_{t}=a_{3}+b_{3} \text { upgrade }_{t}+c_{3} \text { nochange }_{t}+d_{3} \text { big }_{t}+e_{3} \text { noa }_{t-1}+f_{3} \text { ocf }_{t}+\sum \text { g }_{3} \text { year }_{t}+\varepsilon_{3}
$$

where:

no change $=$ dummy variable for changes in disclosure rankings, 1 if a firm's ranking remains unchanged, and 0 otherwise;

upgrade = dummy variable for changes in disclosure rankings, 1 if a firm was given an upgraded ranking, and 0 otherwise;

\section{Empirical Results}

Table 1. The sample period is from 1993 to 2016. OLSmodel: $\mathrm{DA}_{\mathrm{t}}=\mathrm{a}_{1}+\mathrm{b}_{1}$ levelyear $_{\mathrm{t}}+\mathrm{c}_{1}$ big $_{\mathrm{t}}+$ $\mathrm{d}_{1}$ noa $_{\mathrm{t}-1}+\mathrm{e}_{1} \mathrm{ocf}_{\mathrm{t}}+\sum \mathrm{f}_{1}$ year $_{\mathrm{t}}+\varepsilon_{1}$. Standard errors are in parentheses. ${ }^{*},{ }^{* *}$, and ${ }^{* * *}$ denote

\begin{tabular}{|c|c|c|c|c|c|c|}
\hline Method & \multicolumn{6}{|l|}{ OLS } \\
\hline Market & \multicolumn{2}{|c|}{ Main Board } & \multicolumn{2}{|c|}{ SME Board } & \multicolumn{2}{|c|}{ ChiNext Board } \\
\hline Dependent variable & DA & VIF & DA & VIF & $\mathrm{DA}$ & VIF \\
\hline Regression & (1) & & $(2)$ & & (3) & \\
\hline levelyear & $\begin{array}{l}-0.024 * * * \\
(0.006)\end{array}$ & 1.005 & $\begin{array}{l}-0.030 * * * \\
(0.001)\end{array}$ & 2.014 & $\begin{array}{l}-0.030 * * * \\
(0.001)\end{array}$ & 1.974 \\
\hline big4 & $\begin{array}{l}-0.002 \\
(0.002) \\
\end{array}$ & 1.013 & $\begin{array}{l}-0.002 \\
(0.002)\end{array}$ & 1.006 & $\begin{array}{l}-0.015 * * * \\
(0.006)\end{array}$ & 1.029 \\
\hline noa & $\begin{array}{l}-0.008 * * * \\
(0.001)\end{array}$ & 1.030 & $\begin{array}{l}0.011 * * * \\
(0.002)\end{array}$ & 1.718 & $\begin{array}{l}0.012 * * * \\
(0.002)\end{array}$ & 1.989 \\
\hline ocf & $\begin{array}{l}0.016 * * * \\
(0.004)\end{array}$ & 1.020 & $\begin{array}{l}0.014 * * * \\
(0.003)\end{array}$ & 1.206 & $\begin{array}{l}0.005 \\
(0.004)\end{array}$ & 1.366 \\
\hline Year & Yes & & Yes & & Yes & \\
\hline Adj-R2 & 0.0130 & & 0.4164 & & 0.5172 & \\
\hline F-value & 4.12 & & 223.3 & & 178.55 & \\
\hline $\mathrm{N}$ & 4,692 & & 4,986 & & 1,824 & \\
\hline
\end{tabular}
significance at the $10 \%, 5 \%$, and $1 \%$ levels.

Table 1 employs OLS to explore the effect of the disclosure system on earnings management and indicates that DA after the implementation of the system is significantly lower than that before the implementation of the system, supporting H1. This means that after the system, the increased financial information transparency is more likely to decrease the possibility of misleading investors. In order to check multicollinearity, we calculate the variance inflation factors (VIF) for each regress or in the regression model, and when the largest VIF exceeds 10, the problem of multicollinearity is severe and thus multicollinearity is not an issue when making inferences based on these results. 
Table 2. The sample period is from 2001 to 2016. OLSmodel: $\mathrm{DA}_{\mathrm{t}}=\mathrm{a}_{2}+\mathrm{b}_{2}$ level $4_{\mathrm{t}}+\mathrm{c}_{2}$ level $3_{\mathrm{t}}+$ $\mathrm{d}_{2}$ level $_{\mathrm{t}}+\mathrm{e}_{2}$ big $_{\mathrm{t}}+\mathrm{f}_{2}$ noa $_{\mathrm{t}-1}+\mathrm{g}_{2} \mathrm{ocf}_{\mathrm{t}}+\sum \mathrm{h}_{2}$ year $_{\mathrm{t}}+\varepsilon_{2}$. Standard errors are in parentheses. * $* *$, and $* * *$ denote significance at the $10 \%, 5 \%$, and $1 \%$ levels.

\begin{tabular}{|c|c|c|c|c|c|c|}
\hline Method & \multicolumn{6}{|c|}{ OLS } \\
\hline Market & \multicolumn{2}{|c|}{ Main Board } & \multicolumn{2}{|c|}{ SME Board } & \multicolumn{2}{|c|}{ ChiNext Board } \\
\hline Dependent variable & $\overline{\mathrm{DA}}$ & VIF & DA & VIF & DA & VIF \\
\hline Regression & $(1)$ & & $(2)$ & & (3) & \\
\hline level4 & $\begin{array}{l}-0.009 * * * \\
(0.002)\end{array}$ & 2.906 & $\begin{array}{l}-0.016 * * * \\
(0.002)\end{array}$ & 9.065 & $\begin{array}{l}-0.028 * * * \\
(0.003)\end{array}$ & 11.762 \\
\hline level3 & $\begin{array}{l}-0.004 * * \\
(0.002)\end{array}$ & 5.078 & $\begin{array}{l}-0.014 * * * \\
(0.002)\end{array}$ & 9.659 & $\begin{array}{l}-0.029 * * * \\
(0.003)\end{array}$ & 12.542 \\
\hline level2 & $\begin{array}{l}-0.009 * * * \\
(0.002)\end{array}$ & 4.243 & $\begin{array}{l}-0.008 * * * \\
(0.002)\end{array}$ & 4.008 & $\begin{array}{l}-0.026^{* * *} \\
(0.003)\end{array}$ & 4.690 \\
\hline big4 & $\begin{array}{l}-0.002 \\
(0.002)\end{array}$ & 1.023 & $\begin{array}{l}-0.003^{*} \\
(0.002)\end{array}$ & 1.012 & $\begin{array}{l}-0.001 \\
(0.013)\end{array}$ & 1.009 \\
\hline noa & $\begin{array}{l}-0.008^{* * *} \\
(0.002)\end{array}$ & 1.073 & $\begin{array}{l}0.008 * * * \\
(0.002)\end{array}$ & 1.704 & $\begin{array}{l}0.012^{* * *} \\
(0.002)\end{array}$ & 1.874 \\
\hline ocf & $\begin{array}{l}0.017 * * * \\
(0.004)\end{array}$ & 1.026 & $\begin{array}{l}0.018^{* * *} \\
(0.004)\end{array}$ & 1.088 & $\begin{array}{l}0.008 \\
(0.006)\end{array}$ & 1.109 \\
\hline Year & Yes & & Yes & & Yes & \\
\hline Adj-R2 & 0.0202 & & 0.0618 & & 0.1102 & \\
\hline F-value & 5.36 & & 11.81 & & 13.16 & \\
\hline $\mathrm{N}$ & 4,670 & & 2,957 & & 1277 & \\
\hline
\end{tabular}

Table 3. The sample period is from 2001 to 2016. OLSmodel: $\mathrm{DA}_{\mathrm{t}}=\mathrm{a}_{3}+\mathrm{b}_{3}$ upgrade $_{\mathrm{t}}+$ $c_{3}$ nochange $_{t}+d_{3}$ big $_{t}+e_{3}$ noa $_{t-1}+f_{3}$ ocf $_{t}+\sum g_{3}$ year $_{t}+\varepsilon_{3}$. Standard errors are in parentheses. $*$, **, and $* * *$ denote significance at the $10 \%, 5 \%$, and $1 \%$ levels.

\begin{tabular}{|c|c|c|c|c|c|c|}
\hline Method & \multicolumn{6}{|c|}{ OLS } \\
\hline Market & \multicolumn{2}{|c|}{ Main Board } & \multicolumn{2}{|c|}{ SME Board } & \multicolumn{2}{|c|}{ ChiNext Board } \\
\hline Dependent variable & DA & VIF & DA & VIF & $\mathrm{DA}$ & VIF \\
\hline Regression & (1) & & (2) & & (3) & \\
\hline upgrade & $\begin{array}{l}0.002 \\
(0.001)\end{array}$ & 1.678 & $\begin{array}{l}-0.005 * * * \\
(0.001)\end{array}$ & 2.234 & $\begin{array}{l}-0.006 * * * \\
(0.002)\end{array}$ & 2.415 \\
\hline nochange & $\begin{array}{l}0.001 \\
(0.001)\end{array}$ & 1.705 & $\begin{array}{l}-0.004 * * * \\
(0.001)\end{array}$ & 2.225 & $\begin{array}{l}-0.007 * * * \\
(0.001)\end{array}$ & 2.408 \\
\hline big4 & $\begin{array}{l}-0.002 \\
(0.002)\end{array}$ & 1.014 & $\begin{array}{l}-0.005^{* *} \\
(0.002)\end{array}$ & 1.014 & $\begin{array}{l}-0.003^{*} \\
(0.002)\end{array}$ & 1.013 \\
\hline noa & $\begin{array}{l}-0.008 * * * \\
(0.002)\end{array}$ & 1.032 & $\begin{array}{l}0.009 * * * \\
(0.002)\end{array}$ & 1.635 & $\begin{array}{l}0.009 * * * \\
(0.003)\end{array}$ & 1.625 \\
\hline ocf & $\begin{array}{l}0.015^{* * *} \\
(0.004)\end{array}$ & 1.024 & $\begin{array}{l}0.011^{* *} \\
(0.004) \\
\end{array}$ & 1.064 & $\begin{array}{l}0.010 \\
(0.006)\end{array}$ & 1.082 \\
\hline Year & Yes & & Yes & & Yes & \\
\hline Adj-R2 & 0.0086 & & 0.0248 & & 0.040 & \\
\hline F-value & 2.9 & & 5.21 & & 5.5 & \\
\hline $\mathrm{N}$ & 4,399 & & 2648 & & 1,083 & \\
\hline
\end{tabular}

In Table 2, this study explores the relationship between the level of the information transparency and earnings management and reports the empirical results of regression model (2). As shown in Table 2, the results indicate that the proxy for earnings management is negatively and significantly associated with the level, which implies that the more information a company provides to the public, 
the lower earnings management becomes, even in the presence of the control variables, consistent with H2. In addition, the VIFs for these variables are all less than 4, and thus multicollinearity is not an issue when making inferences based on these results.

Moreover, in order to test the third hypothesis with regard to whether firms with a ranking upgrade are more likely to decrease earnings management than firms with a ranking downgrade, this study sorts firms into three groups, namely, upgraded, unchanged, and downgraded, based on the assessments made by the system, and the estimation results estimated are presented in Table 3 . The results show that except for the market Main Board, the coefficients of upgrade and no change are significantly negative, implying that firms with a ranking upgrade are less likely to manipulate earnings management than those that are given a downgraded ranking, giving support to the third hypothesis.

\section{Conclusions}

This study examines the relationship between the information transparency and earnings management, hypothesizing that they are negatively related. Further, it uses ratings published by SZSE to measure disclosure levels, and DA to measure earnings management. Our results indicate that after the implementation of the system firms are more likely to rationalize earnings management than before it. As for changes in disclosure rankings, firms with an upgraded ranking are less likely to use earnings management than those with a downgraded ranking. The system has thus enhanced the quantity and quality of information disclosure by SZSE listed companies, both of which are instrumental in the reduction of earnings management.

For regulators, the top priority is to establish mechanisms (e.g., the information disclosure system) to alleviate the asymmetric information. Similar to prior research (Chang et al., 2012 [11]), our results suggest that policy-making bodies should oblige firms to disclose more information, and even set minimum disclosure requirements, by enacting more detailed regulations than those contained in the system, because these may play a significant role in restraining earnings management.

For academics, future researchers exploring the determinants of earnings management could consider the role of different information disclosure rankings in different ranking scheme.

For investors, this study shows a negative relationship between both the level and the changes in the level of disclosure and earnings management, and suggests that the government should continue to enforce the system, and even set minimum disclosure requirements for firms. This will help further reduce the information asymmetry between insiders and outsiders, and increase investors' ability to assess and monitor managers' investment decisions. Lai et al. (2012) [10] document that increased levels of disclosure can reduce information asymmetry, which in turn improves capital investment efficiency, and thus that investors can view firms with higher disclosure levels as having greater investment efficiency when assessing their value.

\section{Acknowledgement}

The author thanks Beijing Normal University Library at Zhuhai Campus (http://library.bnuz.edu.cn/) and RESSET Financial Research Database (http://www.resset.cn)for excellent research assistance. This paper is supported by Beijing Normal University Zhuhai Campus (http://www.bnuz.edu.cn/).

\section{References}

[1] Healy, P. M., Hutton, A. P., \&Palepu, K. G. (1999). Stock Performance and Intermediation Changes Surrounding Sustained Increases in Disclosure. Contemporary Accounting Research, 16(3), 485-520.

[2] Akerlof, G. A. (1970). The Market for 'Lemons': Quality Uncertainty and the Market Mecha-nism. Quarterly Journal of Economics, 84(3), 488-500. 
[3] Joe, J. R. (2003). Why press coverage of a client influences the audit opinion. Journal of Accounting Research, 41, 109-133.

[4] Wang, W., \& Jiang, G. F. (2004). Information Disclosure ,Transparency and the Cost of Capital. Economic Research Journal, 7, 107-114.

[5] Zeng, Y., \& Lu, Z. F. (2006). The Relationship between Disclosure Quality and Cost of Equity Capital of Listed Companies in China. Economic Research Journal, 2, 69-91.

[6] Zhang, B., Van, Z. H., \& Pan, J. C. (2009). Information Transparency and Corporate performance. Journal of Financial Research, 2, 169-184.

[7] Cheng, G. h., \& Wang, W. J. (2011). The Impact of the Quality of Internal Control on Corporate Performance. Lanzhou Academic Journal, 4, 54-58.

[8] Li, X., \& Zhang, G. Z. (2013). The Impact of Information Disclosure Quality on Financial Performance. Journal of Financial Development Research, 6, 68-72.

[9] Jiao, Y. (2011). Corporate disclosure, market valuation, and firm performance. Financial Management, 40(3), 647-676.

[10] Lai, S. M., Liu, C. L., \& Wang, T. C. (2012). Increased disclosure and investment efficiency. Asia-Pacific Journal of Accounting \& Economics, 1-20.

[11] Chang, H., Chang, R. D., \& Fang, C. J. (2012). The effects of information transparency on analysts' forecasts: Evidence from the information disclosure and transparency ratings system in Taiwan. Asia-Pacific Journal of Accounting \& Economics, 1-24. 